\title{
Continuing Support for Elderly Dogs
}

\author{
Ronald Lagoe $^{1 *}$, Taylor Rae Schreiber ${ }^{2}$ and Meghan Slanina ${ }^{3}$ \\ ${ }^{1}$ The Ruthie Foundation, Syracuse, USA \\ ${ }^{2}$ Fairmount Animal Hospital, Syracuse, USA
}

${ }^{3}$ The Ruthie Foundation, Cincinnati, OH, USA

*Corresponding author: Ronald Lagoe, The Ruthie Foundation, Syracuse, New York, 13235, USA

\section{ARTICLE INFO}

Received: 慧 May 18, 2021

Published: 慧 May 28, 2021

\section{ABSTRACT}

Citation: Ronald Lagoe, Taylor Rae Schreiber. Continuing Support for Elderly Dogs. Biomed J Sci \& Tech Res 36(1)-2021. BJSTR. MS.ID.005808.

\section{Opinion}

During 2014, a number of individuals in Upstate New York established a small organization to support the care of elderly dogs. It was named The Ruthie Foundation in honor of a small black and tan miniature dachshund who lived more than twenty years. The initial years of The Ruthie Foundation focused on organizational issues and providing care for a small number of elderly dogs. This narrative describes the continued evolution of the Foundation since that time.

\section{Program Issues}

The most important function of The Ruthie Foundation continues to focus on supporting the ability of caregivers to support elderly dogs. It has been recognized that the expenses of providing veterinary care, medications, and food have increased for caregivers of these dogs. In Central New York, the costs of veterinary visits have increased at practices used by dogs supported by the Foundation. Pharmaceutical costs have also increased at small and large practices. Expenses for food, especially prescription medications, have also increased. The Foundation has been aware that these costs have been a challenge for some caregivers. It is committed to help maintain these dogs at home. The Foundation has continued care for a wide range of dogs. Consistent with Ruthie's background, a number of them have been dachshunds. The need for support for these dogs has been confirmed by participating veterinarians and the Foundation staff. In addition to these forms of care, The Ruthie Foundation has also developed support for additional services during the past three years. These have included transportation of shelter dogs being adopted by caregivers in the Central New York area. Three of these dogs have been transported from locations in Pennsylvania and Delaware. The costs of transporting these dogs have been subsidized by the Foundation.

\section{Financial Issues}

During the first three years of The Ruthie Foundation, total annual revenue ranged between $\$ 10,000$ - \$7,500. Between 2019 and 2021 , incoming revenue was $\$ 5,600-\$ 5,800$ per year. This development appeared to reflect a stabilization of incoming revenue within this range. This revenue was contributed by a small number of donors in the Central New York area. The reduction in revenue may also be related to the impact of the Coronavirus epidemic on funds available from private sources. This has included family and employer support. In the first three years of the organization, approximately fifty percent of Foundation expenses were devoted to startup costs. These included legal expenses associated with development of the tax-exempt status, website development, and other organizational costs. These expenses were provided at little or no cost by the volunteer staff and by residents of the Central New York area. Based on these expenses, this information suggested that the decision to use volunteer staff was a sound one. The experiences of recent years indicated that the organization could not have supported a paid staff.

During the past few years, volunteer staff have been effective in providing financial services for the foundation. This has included identifying expenses and sending checks to recipients of funding 
and administrative expenses. It has also included completion of the annual federal Return of Organization Exempt from Taxation, Form 990.

\section{Conclusion}

The initial years of The Ruthie Foundation have provided opportunities for small caregiving initiatives with the burden of

ISSN: 2574-1241

DOI: 10.26717/BJSTR.2021.36.005809

Ronald Lagoe. Biomed J Sci \& Tech Res

(c) (P) This work is licensed under Creative

Submission Link: https://biomedres.us/submit-manuscript.php extensive assets and obligations. Continuing activities will focus on identification of fund-raising activities and services that can be implemented within this framework. They may also include development of relationships with other organizations interested in supporting the care of elderly dogs.

$\begin{array}{ll}\text { BIOMEDICAL } & \text { Assets of Publishing with us } \\ \text { RESEARCHES } & \text { - Global archiving of articles } \\ \text { - Immediate, unrestricted online access } & \text { - Rigorous Peer Review Process } \\ & \text { - Authors Retain Copyrights } \\ & \end{array}$

